УДК 342.565.5 (477)

DOI https://doi.org/10.32782/2409-4544/2019-2/11

В. Кравчук

\title{
Вимога щодо юридичної освіти та стажу професійної діяльності як структурний елемент конституційно-правового статусу суддів в Украӥні
}

Стаття присвячена аналізу вітчизняного і зарубіжного конституційного законодавства про судоустрій і статус суддів в частині вимоги про юридичну освіту і стаж професійної діяльності. Обгрунтовано, що дослідження природи інституту конституційно-правового статусу суддів неможливе без характеристики його складових елементів. До останнього часу в науці конституційного права не створено теоретичних підстав для вимоги про юридичну освіту і стаж професійної діяльності для кандидатів на посаду судді. Проведений аналіз свідчить, що чинна редакція ч. 3 ст. 127 Конституції України враховує позитивний зарубіжний досвід і у цілому відповідає європейським демократичним стандартам, а конституційні положення конкретизуються у відповідному спеціальному законі. Вимога щодо юридичної освіти та стажу професійної діяльності для суддів є додатковим (неосновним) елементом їх правового статусу, оскільки впливає на обсяг їхніх прав і обов'язків. Крім того, вимога про юридичну освіту і стаж професійної діяльності для кандидатів на посади судді обумовлена потребами забезпечення неупередженого, об'єктивного i своєчасного правосуддя для фізичних та юридичних осіб, що має здійснюватися кваліфікованими суддями з належним рівнем професійної підготовки. Автор вважає, що збільшення стажу професійної діяльності у сфері права з трьох років до п'яти років є необхідним для більш грунтовного оволодіння професійними знаннями, навичками та вміннями, які є необхідними для здійснення правосуддя. Проте, застосування категорії «сфера права» при класифікації видів професійної юридичної діяльності створює певні ускладнення через свою загальність, а тому необхідним є його офіційне тлумачення.

Ключові слова: конституційно-правовий статус суддів; правовий статус суддів; стаж професійної діяльності; суддя; юридична освіта.

Постановка наукової проблеми та її значення. Дослідження природи інституту конституційно-правового статусу суддів є неможливим без характеристики його складових елементів. Вітчизняними та зарубіжними нормативно-правовими актами визначаються вимоги, що пред’являються до суддів в цілому, та вимога щодо юридичної освіти та стажу професійної діяльності, зокрема. Проте, до останнього часу в науці конституційного права не створено теоретичних засад вимоги щодо юридичної освіти та стажу професійної діяльності, немає фундаментальних наукових досліджень цієї проблеми.

Актуальність теми дослідження зумовлена комплексним характером вимоги щодо юридичної освіти та стажу професійної діяльності, що пред'являються до суддів як правового інституту, що складається 3 норм різних галузей національного законодавства. Така особливість правової регламентації вимоги юридичної освіти та стажу професійної діяльності вимагає єдиної концептуальної спрямованості цих норм.

Аналіз останніх досліджень і публікацій, у яких започатковано розв'язання даної проблеми. Дослідження правового статусу суддів як суб' єктів конституційно-правових відносин у будь-який час розвитку та становлення конституційно-правової доктрини не втрачали своєї актуальності та становили доволі високий відсоток від загального обсягу теоретичних напрацювань в цій сфері. У вітчизняній юридичній науці до питання вимог, що пред’являються до суддів частково зверталися у своїх дослідженнях такі вчені, як В. Сгорова, О. Лагнюк, А. Марцинкевич, Д. Шпенов, О. Юшкевич та інші. Однак, на жаль, лише в деяких працях приділялась увага проблематиці, пов'язаній з вимогою щодо юридичної освіти та стажу професійної діяльності (I. Марочкін).

Мета й завдання статті. Мета даної статті полягає у пошуку та виявленні шляхів вирішення актуальних теоретичних проблем вимоги щодо юридичної освіти та стажу професійної діяльності кандидатів на посади суддів в Україні та зарубіжних країнах, урахування позитивного досвіду останніх.

Виклад основного матеріалу й обгрунтування отриманих результатів дослідження.

(C) Кравчук В., 2019 
Відповідно до ч. 3 ст. 127 Конституції України на посаду судді може бути призначений громадянин України, не молодший тридцяти та не старший шістдесяти п'яти років, який має вищу юридичну освіту і стаж професійної діяльності у сфері права щонайменше п'ять років, $є$ компетентним, доброчесним та володіє державною мовою. Законом можуть бути передбачені додаткові вимоги для призначення на посаду судді. А частина четверта цієї ж статті Основного Закону встановлює, що для суддів спеціалізованих судів відповідно до закону можуть бути встановлені інші вимоги щодо освіти та стажу професійної діяльності [1].

В зарубіжних конституціях часто зустрічаються норми, в яких містяться схожі до українських, за змістом кваліфікаційні вимоги щодо юридичної освіти та стажу професійної діяльності. Так, ст. 119 Конституції Російської Федерації декларує: «суддями можуть бути громадяни Російської Федерації, які ...мають вищу юридичну освіту і стаж роботи зі спеціальності не менш 5 років...» [2], ст. 126 Конституції Азербайджанської Республіки встановила, що «суддями можуть бути громадяни Азербайджанської Республіки, які ...мають вищу юридичну освіту і стаж роботи по юридичній спеціальності не менше 5 років» [3], ст. 83 Конституції Киргизької Республіки встановила, що «суддею місцевого суду може бути громадянин Киргизької Республіки, ...який має вищу юридичну освіту і стаж роботи по юридичній професії не менше 5 років; а суддею Верховного Суду може бути громадянин Киргизької Республіки, ...який має вищу юридичну освіту і стаж роботи по юридичній професії не менше 10 років» [4].

Зустрічаються конституційно закріплені приклади, котрі детальніше, ніж в Конституція України, закріплюють кваліфікаційні вимоги юридичної освіти та стажу професійної діяльності. Наприклад, в ст. 59 Конституції Домініканської Республіки встановлено, що для того щоб бути суддею Верховного суду, необхідно ...бути адвокатом або доктором права, що працює за своєю спеціальністю не менше восьми років, або обіймати протягом чотирьох років посади судді будь-якого суду або трибуналу [5].

В даному контексті варта уваги ще одна принципова обставина, а саме, що чинний Закон України «Про судоустрій і статус суддів» додатково встановлює перелік професійної діяльності у сфері права для суддів апеляційного суду (стаж роботи на посаді судді не менше п'яти років; науковий ступінь у сфері права та стаж наукової роботи у сфері права щонайменше сім років; досвід професійної діяльності адвоката, в тому числі щодо здійснення представництва в суді та/або захисту від кримінального обвинувачення щонайменше сім років), Вищого суду з питань інтелектуальної власності (стаж роботи на посаді судді не менше трьох років; досвід професійної діяльності представника у справах інтелектуальної власності (патентного повіреного) щонайменше п'ять років; досвід професійної діяльності адвоката щодо здійснення представництва в суді у справах щодо захисту прав інтелектуальної власності щонайменше п'ять років) та Верховного Суду (стаж роботи на посаді судді не менше десяти років; науковий ступінь у сфері права та стаж наукової роботи у сфері права щонайменше десять років; досвід професійної діяльності адвоката, в тому числі щодо здійснення представництва в суді та/або захисту від кримінального обвинувачення щонайменше десять років) [6].

Проведений вище аналіз свідчить, що чинна редакція ч. 3 ст. 127 Конституції України враховує позитивний зарубіжний досвід та в цілому, відповідає європейським демократичним стандартам, а конституційні положення конкретизуються у відповідному спеціальному законі.

Статтею 6 Закону Республіки Молдова «Про статус суддів» закріплено, що кандидатом на посаду судді може бути особа, яка ...отримала диплом ліценціата права; має стаж роботи за юридичною спеціальністю, необхідною для зайняття посади, на яку претендує... Суддею суду може бути призначена особа, яка ... має стаж роботи за юридичною спеціальністю не менше п'яти років, та успішно склала кваліфікаційний іспит. Суддею апеляційної палати або Вищої судової палати може бути призначена особа, що має стаж роботи на посаді судді відповідно не менше шести і не менше десяти років [7].

Згідно з ст. 94 Кодексу Республіки Білорусь «Про судоустрій і статус суддів» кандидатом на посаду судді загального або господарського суду може бути громадянин Республіки Білорусь, який ...має вищу юридичну освіту із присвоєнням кваліфікації «юрист», стаж роботи за спеціальністю не менше трьох років, порядок обрахування якого визначається Урядом Республіки Білорусь або уповноваженим ним органом... [8].

Органічним законом Грузії «Про загальні суди» встановлено, що суддею може бути призначений (обраний) дієздатний громадянин Грузії, який ...має вищу юридичну освіту, академічний степінь не нижчий магістра або прирівняного до нього/диплом про вищу освіту, досвід роботи за спеціальністю не менше 5 років... [9]. 
Відповідно до ст. 61 Закону Республіки Узбекистан «Про суди» суддею міжрайонного, районного (міського) суду 3 цивільних справ, районного (міського) суду 3 кримінальних справ, районного (міського) економічного суду, районного (міського) адміністративного, територіального військового суду може бути громадянин Республіки Узбекистан ...що має вищу юридичну освіту і стаж роботи за юридичною спеціальністю, передусім у правоохоронних органах, не менше п'яти років [10].

Конституційним Законом Киргизької Республіки «Про Статус суддів Киргизької Республіки» передбачено: 1) суддею Верховного суду може бути громадянин Киргизької Республіки ...що має вищу юридичну освіту за спеціальністю «Юриспруденція» або вищу освіту за напрямом підготовки «Юриспруденція» 3 присвоєнням академічного ступеня «магістр» при наявності академічного ступеня «бакалавр» за відповідним напрямом і стаж роботи за юридичною професією не менше десяти років (ч. 1 ст. 15); 2) суддею Конституційної палати Верховного суду може бути громадянин Киргизької Республіки ...що має вищу юридичну освіту за спеціальністю «Юриспруденція» або вищу освіту за напрямом підготовки «Юриспруденція» 3 присвоєнням академічного ступеня «магістр» при наявності академічного ступеня «бакалавр» за відповідним напрямом і стаж роботи за юридичною професією не менше п'ятнадцяти років, володіє державною та офіційною мовами (ч. 2 ст. 15); 3) суддею місцевого суду може бути громадянин Киргизької Республіки ...що має вищу юридичну освіту за спеціальністю «Юриспруденція» або вищу освіту за напрямом підготовки «Юриспруденція» 3 присвоєнням академічного ступеня «магістр» при наявності академічного ступеня «бакалавр» за відповідним напрямом і стаж роботи за юридичною професією не менше п’яти років (ч. 1 ст. 17) [11].

Статтею 29 Конституційного Закону Республіки Казахстан «Про судову систему і статус суддів Республіки Казахстан» встановлені наступні вимоги, що пред'являються до кандидатів у судді: I. Суддею районного суду може бути призначений громадянин Республіки Казахстан, який: ...має вищу юридичну освіту, ... i, як правило, не менше п'яти років стажу роботи секретарем судового засідання, консультантом (помічником) суду, прокурора, адвоката або не менше десяти років стажу роботи за юридичною професією... II. Суддею обласного суду може бути громадянин, що ....має стаж роботи за юридичною професією не менше п'ятнадцяти років, з них стаж роботи суддею не менше п'яти років... III. Суддею Верховного Суду може бути громадянин, що ...має стаж роботи за юридичною професією не менше двадцяти років, з них не менше десяти років стажу роботи суддею, в тому числі п’яти років стажу роботи суддею обласного суду... [12].

Відповідно до Закону Латвійської республіки про судову владу, при виборі кандидатів на посаду судді варто дотримуватись принципу, що суддею може працювати лише громадянин Латвії висококваліфікований та чесний юрист [13].

Статтею 9 Закону Китайської Народної Республіки «Про суддів» посаду судді може обіймати особа, яка ...має, як мінімум, дворічний стаж роботи, у випадку, якщо закінчила коледж або університет за юридичним фахом чи закінчила коледж або університет не за юридичним фахом, але при цьому володіє професійним знанням закону; або особа, що має, як мінімум річний стаж роботи, якщо ця особа має ступінь бакалавра права; на осіб, що мають ступінь магістра права або доктора права, вимога володіння стажем роботи не розповсюджується [14].

У Франції відповідно до ст. 16 Органічного закону про статус магістратури кандидати в магістрати повинні мати диплом про другий цикл вищої освіти або будь-який документ чи диплом того ж рівня... [15].

Відповідно до п. 1 ч. 6 ст. 69 Закону України «Про судоустрій і статус суддів» вищою юридичною освітою є вища юридична освіта ступеня магістра (або прирівняна до неї вища освіта за освітньо-кваліфікаційним рівнем спеціаліста), здобута в Україні, а також вища юридична освіта відповідного ступеня, здобута в іноземних державах та визнана в Україні в установленому законом порядку. Пунктом другим частини шостої статті 69 цього ж закону встановлюється, що стажем професійної діяльності у сфері права $є$ стаж професійної діяльності особи за спеціальністю після здобуття нею вищої юридичної освіти [6]. Збільшення ж стажу професійної діяльності з трьох років до п'яти років $\epsilon$ необхідним для більш грунтовного оволодіння професійними знаннями, навичками та вміннями, які є необхідними для здійснення правосуддя. Переконані, що грунтовні професійні знання, навички та вміння для будь-якої людини, в тому числі і для кандидата на посаду судді, приходять 3 роками наполегливої та цілеспрямованої роботи.

Проте, застосування категорії «сфера права» при класифікації видів професійної юридичної діяльності створює певні ускладнення через свою загальність. В Конституції України і Законі України «Про судоустрій і статус суддів» відсутня конкретизація, в якій сфері права повинен працювати громадянин, що претендує на посаду судді. Тому можна зробити висновок, що професійна діяльність 
громадянина в будь-якій сфері права дає йому можливість претендувати на посаду судді. Зазначимо, що коло осіб, які працюють в сфері права, є досить широким: адвокати, прокурори, секретарі судових засідань, слідчі, вчені-юристи, нотаріуси, юрисконсульти, судові виконавці, державні службовці та ін.

Крім цього, Рішенням Конституційного Суду України у справі про стаж для зайняття посади судді в апеляційних, вищих спеціалізованих судах та Верховному Суді України від 5 квітня 2011 року встановлено, що стаж роботи на посаді судді $€$ різновидом стажу роботи в галузі права [16]. У листі Міністерства юстиції України від 30 вересня 2009 року щодо виконання вимог Закону України «Про нотаріат» повідомляється, що до стажу роботи у сфері права зараховується період роботи на посадах 3 реалізацією повноважень, пов'язаних 3 правоохоронними, правовиконавчими, правоустановчими функціями. За змістом робота у сфері права передбачає розробку або застосування норм права i носить систематичний характер. Вважаємо, що це період роботи в органах державної влади (в тому числі в судах, органах юстиції, прокуратури), нотаріату, адвокатури, місцевого самоврядування, у профспілкових та інших громадських організаціях, на підприємствах, в установах, організаціях будьякої форми власності [17].

3 даного приводу абсолютно обгрунтованими є сумніви професора I. Марочкіна стосовно того, чи всяка діяльність в галузі права робить юристів професіоналами, які будуть готові повноцінно здійснювати функції носіїв судової влади. Вузька юридична спеціалізація, відсутність практичного досвіду кримінального, цивільного та адміністративного процесу аж ніяк не $є$ критеріями професіоналізму юристів та ознакою якості корпусу суддів. Тому, вчений вважає, що оптимальним буде варіант, якщо стаж роботи в галузі права за юридичною спеціальністю набуватиметься в якості прокурора, помічника судді, прокурора, адвоката, юриста (захисника в кримінальних, адміністративних чи представника в цивільних справах). Саме практикуючі в судових справах юристи повинні складати більшість кандидатів на суддівські посади. Крім того, на думку I. Марочкіна, для досягнення єдності в роботі кваліфікаційних комісій суддів з оцінки якості «стажу роботи в галузі права» кандидатів на посади суддів доцільно розробити Інструкцію про порядок визначення стажу роботи у галузі права для кандидатів на посади суддів, де, крім переліку робіт у галузі права, варто передбачити повноваження кваліфікаційних комісій суддів з перевірки даних про стаж роботи кандидата [18, с. 18]. На нашу думку, дані питання повинні бути предметом не підзаконного нормативно-правового акту, а Закону України «Про судоустрій і статус суддів».

Висновки. Отже, вимога щодо юридичної освіти та стажу професійної діяльності кандидатів на посади суддів є додатковим (неосновним) структурним елементом їх правового статусу, оскільки впливає на обсяг їх прав та обов'язків. Крім того, вимога щодо юридичної освіти та стажу професійної діяльності кандидатів на посади суддів зумовлена потребами гарантування для фізичних та юридичних осіб неупередженого, об'єктивного та своєчасного правосуддя, здійснюваного кваліфікованими суддями з належним рівнем професійної підготовки.

\section{Джерела та література}

1.Конституція України прийнята на п’ятій сесії Верховної Ради України 28 червня 1996 року, 3 наступними змінами [Електронний ресурс]. - Режим доступу: http://zakon0.rada.gov.ua/laws/show/254к/96-вр/ed19960628.

2. Конституція Російської Федерації від 12 грудня 1993 року, з наступними змінами [Електронний pecypc]. - Режим доступу: http://www.constitution.ru.

3. Конституція Азербайджанської Республіки від 12 листопада 1995 року, з наступними змінами [Електронний pecypc]. - Режим доступу: http://www.azerbaijan.az/portal/General/ Constitution/doc/constitution_r.pdf.

4. Конституція Киргизької Республіки від 27 червня 2010 року, з наступними змінами. [Електронний pecypc]. - Режим доступу: http://www.gov.kg/?page_id=263\&lang=ru.

5. Конституція Домініканської Республіки від 10 січня 1947 року, 3 наступними змінами. [Електронний ресурс]. - Режим доступу: http://worldconstitutions.ru/?p=46\&page=2.

6. Про судоустрій і статус суддів: Закон України від 2 червня 2016 р., 3 наступними змінами [Електронний pecypc]. - Режим доступу: http://zakon3.rada.gov.ua/laws/show/140219/print1465331835457898.

7. Закон Республики Молдова «О статусе судьи» от 20 июля 1995 года, из следующими изменениями. [Електронний ресурc]. - Режим доступу: http://www.cnas.md/libview.php?l=ru\&idc=183\&id=555.

8. Кодекс Республики Беларусь «О судоустройстве и статусе судей» от 29 июня 2006 года, с последующими изменениями [Електронний ресурс]. - Режим доступу: 
http://www.kc.gov.by/main.aspx?guid=21725.

9. Органический закон Грузии «Об общих судах» от 4 декабря 2009 года, с изменениями. [Електронний ресурс]. - Режим доступу: http://www.refworld.org.ru/docid/548f0a774.html.

10. Закон Республики Узбекистан «О судах» от 14 декабря 2000 года, с изменениями [Електронний pecypc]. - Режим доступу: http://lex.uz/pages/GetAct.aspx?lact_id=68521.

11. Конституционный Закон Кыргызской Республики «О статусе судей Кыргызской Республики» от 9 июля 2008 года, с изменениями [Електронний ресурс]. - Режим доступу: http://cbd.minjust.gov.kg/act/view/ru-ru/202352.

12. Конституционный Закон Республики Казахстан «О судебной системе и статусе судей Республики Казахстан» от 25 декабря 2000 года, с изменениями и дополнениями [Електронний ресурс]. - Режим доступу: http://sud.gov.kz/rus/content/konstitucionnyy-zakon-o-sudebnoy-sisteme-i-statuse-sudey.

13. Закон Латвийской Республики «О судебной власти» от 15 декабря 1992 года, с следующими изменениями [Електронний ресурс]. - Режим доступу: http://worldconstitutions.ru/?p=891.

14. Закон Китайской Народной Республики «О судьях» от 1 июля 1995 года, с изменениями [Електронний ресурс]. - Режим доступу: http://law.uglc.ru/judge.htm.

15. Органический закон Франции «О статусе магистратуры» от 22 декабря 1958 года, с изменениями [Електронний ресурс]. - Режим доступу: http://worldconstitutions.ru/?p=877.

16. Рішення Конституційного Суду України у справі за конституційним поданням 49 народних депутатів України щодо відповідності Конституції України (конституційності) окремих положень частини четвертої статті 26, частини третьої статті 31, частини другої статті 39 Закону України «Про судоустрій і статус суддів» (справа про стаж для зайняття посади судді в апеляційних, вищих спеціалізованих судах та Верховному Суді України) № 3-рп/2011 від 5 квітня 2011 р. [Електронний pecypc]. - Режим доступу: http://www.ccu.gov.ua/docs/622.

17. Лист Міністерства юстиції України від 30 вересня 2009 року № 31-32/310 щодо виконання вимог Закону України «Про нотаріат» [Електронний ресурс]. - Режим доступу: http://zakon3.rada.gov.ua/laws/show/v_310323-09.

18. Марочкін I. Є. Добір кандидатів на посади суддів / I. Є.Марочкін // Інформаційний вісник Вищої кваліфікаційної комісії суддів України. - 2007. - Вип. 1. - С. 12-34.

Кравчук В. Требование о юридическом образованиия и стаже профессиональной деятельности как структурный элемент конституционно-правового статуса судей в Украине. Статья посвящена анализу отечественного и зарубежного конституционного законодательства о судоустройстве и статусе судей в части требования о юридическом образовании и стаже профессиональной деятельности. Обосновано, что исследования природы института конституционноправового статуса судей невозможно без характеристики его составляющих элементов. До последнего времени в науке конституционного права не создано теоретических оснований требования о юридическом образовании и стаже профессиональной деятельности для кандидатов на должность судьи. Проведенный анализ свидетельствует, что действующая редакция ч. 3 ст. 127 Конституции Украины учитывает положительный зарубежный опыт и в целом соответствует европейским демократическим стандартам, а конституционные положения конкретизируются в соответствующем специальном законе. Требование в отношении юридического образования и стажа профессиональной деятельности для судей является дополнительным (не основным) элементом их правового статуса, поскольку влияет на объем их прав и обязанностей. Кроме того, требование о юридическом образовании и стаже профессиональной деятельности кандидатов на должности судей обусловлено потребностями обеспечения беспристрастного, объективного и своевременного правосудия для физических и юридических лиц, осуществляемого квалифицированными судьями с должным уровнем профессиональной подготовки. Автор считает, что увеличение стажа профессиональной деятельности в сфере права с трех лет до пяти лет необходимо для более основательного овладения профессиональными знаниями, навыками и умениями, которые необходимы для осуществления правосудия. Однако, применение категории «сфера права» при классификации видов профессиональной юридической деятельности создает определенные сложности из-за своей обобщенности, а потому необходимо его официальное толкование.

Ключевые слова: конституционно-правовой статус судей; правовой статус судей; стаж профессиональной деятельности в соответствии требования по юридического образования и стажа профессиональной деятельности ти; судья; юридическое образование.

Kravchuk V. The Requirement for Legal Education and Professional Experience as a 
Structural Component of the Constitutional and Legal Status of Judges in Ukraine. The article is devoted to the analysis of the Ukrainian and foreign constitutional legislation on the judicial system and the status of judges in terms of the requirements for legal education and professional experience. The key findings of the research argue that the study of the nature of the constitutional and legal status of judge institute is not possible without characterization of its constituent elements. Until recently, the requirements for legal education and professional experience in the constitutional law science lack theoretical grounding. The analysis shows that the current wording of Part 3 of Article 127 of the Constitution of Ukraine takes into account the positive foreign experience and, in general meets the European democratic standards, and the constitutional provisions are specified in the relevant special law. The requirement for legal education and professional experience is an additional (non-core) element of the judge's legal status as it affects the scope of his rights and responsibilities. In addition, the requirement for legal education and professional experience of candidates for judicial office is conditioned by the need to guarantee for the individuals and legal entities impartial, objective and timely justice, provided by qualified judges with the proper level of professional training. The author believes, that increasing the length of professional experience in the field of law from three to five years is necessary for a more thorough mastery of professional knowledge, skills and abilities that are necessary for the administration of justice. However, the using of the category «area of the law» in the classification of professional legal activities creates certain complications due to its generality, and therefore its official interpretation is necessary.

Key words: constitutional and legal status of judges; legal status of judges; professional experience as required by legal education and professional experience; judge; legal education.

УДК 34:061.1 ЄС

DOI https://doi.org/10.32782/2409-4544/2019-2/12

О. Юхимюк

\section{Функції принципів права Європейського Союзу в практиці Суду Європейського Союзу}

У статті проведено функціональний аналіз принципів права Європейського Союзу в практиці Суду Європейського Союзу. Досить загальний вміст норм права Європейського Союзу, їх повна або часткова відсутність призводять до зростання значення принципів права в практиці Суду Європейського Союзу. Принципи права Європейського Союзу в практиці Суду Європейського Союзу реалізують ряд завдань, до яких зокрема належать: заповнення прогалин у праві Свропейського Союзу; інтеграція правової системи Свропейського Союзу у цілому, правових систем країн-членів Європейського Союзу, а також країн, що прагнуть до членства в Європейського Союзу; установча функція, яка полягає у формуванні окремої правової наднаціональної системи Європейського Союзу. Принципи права Європейського Союзу в практиці Суду Європейського Союзу виступають додатковим, але не другорядним інструментом тлумачення і застосування установчих договорів Європейського Союзу; забезпечення і захист прав людини, формування інституту громадянства Європейського Союзу. Саме принципи права виступають засобом заповнення прогалин як у правозастосовчій діяльності інститутів Європейського Союзу, так і безпосередньо в практиці Суду Справедливості. Завдяки принципам права можуть вирішуватися питання, не врегульовані правом Європейського Союзу, що, однак не означає можливості Суду Справедливості механічно посилатись на принципи права держав-членів. Створюючи і застосовуючи принципи права, Суд Справедливості фактично реалізує квазі-гармонізацію, яка не лише зближує правові системи держав-членів Європейського Союзу, але й країн, що прагнуть до членства в Європейському Союзу. Принципи права також є інструментом не лише застосування, а й належного розуміння і тлумачення права Європейського Союзу. Принципи права мали й матимуть надалі винятковий вплив на доктрину права Європейського Союзу, зокрема принципи верховенства права, недискримінації та інші.

Ключові слова: принципи права, принципи права Європейського Союзу, Суд Справедливості Європейського Союзу.

(С) Юхимюк О., 2019 